Justus von Geibler, Kora Kristof, Katrin Bienge

Sustainability assessment of entire forest value chains:

Integrating stakeholder perspectives and indicators in decision support tools

Originally published as:

Von Geibler et al. (2010):

Sustainability assessment of entire forest value chains: Integrating stakeholder perspectives and indicators in decision support tools

In: Ecological Modelling, 221, 18, 2206-2214 
Justus von Geibler ${ }^{a,{ }^{*}}$, Kora Kristof ${ }^{\text {a }}$, Katrin Bienge ${ }^{\text {a }}$

Sustainability assessment of entire forest

value chains:

Integrating stakeholder perspectives and indicators in decision support tools

a Wuppertal Institute for Climate, Environment and Energy, Research Group Sustainable Production and Consumption, Wuppertal, Germany

* Corresponding author: Dr. Justus von Geibler, Wuppertal Institute for Climate, Environment and Energy, Doeppersberg 19, 42103 Wuppertal, Germany

E-mail: justus.geibler@wupperinst.org

Phone: +49-202-2492-168

Fax: $+49-202-2492-138$ 


\title{
Sustainability assessment of entire forest value chains: \\ Integrating stakeholder perspectives and indicators in decision support tools
}

\author{
Dr. Justus von Geibler, Dr. Kora Kristof, Katrin Bienge \\ Wuppertal Institute for Climate, Environment and Energy, \\ Research Group Sustainable Production and Consumption, Wuppertal, Germany \\ Contact email: justus.geibler@wupperinst.org
}

Accepted author manuscript of a paper for the special issue "Tools and Methods of Decision Support Systems for Policy Impact Assessment" of the Journal "Ecological Modelling”

Guest editors of the Special Issue: Stefan Sieber (ZALF), Peter Zander (ZALF), Peter Verbourg (WURL,

Wageningen), Martin van Ittersum (WURL, Wageningen)

\section{Introduction}

How can the contribution of entire value chains to sustainable development be assessed? How can the results be communicated to decision makers to promote sustainable development? This article addresses these questions and presents a methodological approach for the development of sustainability indicator sets of value chains and its integration into a practical decision support tool in the specific case study of the chain "construction and refurbishment with wood". The article highlights that developing a value chain wide indicator set based on a participatory stakeholder approach is an important step for optimizing the interaction between human and ecological systems.

Within current production and consumption patterns, value chains are important causal links between human activity and environmental change. Value chains combine key driving forces for ecological change, however, as the continued destruction of key ecosystem services indicates (Millennium Ecosystem Assessment, 2005), in many cases their development does not take negative effects on ecological systems into account. Consequently, methods and tools are needed to support decision makers in value chains to avoid and reduce negative impacts on environmental and social systems. In order to be successful, these methods and tools need 
to be trouble-free and should be custom-made for the decision makers. Thus, they can only be developed in a specific context.

This paper focuses on the case study of value chain "construction and refurbishment with wood". In its overall context, the increased use and disposal of biomass building materials have a tremendous impact on natural resources, including forest resources. Thus, there is need for action. Despite the fact that numerous indicator sets for sustainable development of forests and sustainable forestry are available at different levels, and some efforts have been made to integrate later production stages of forest value chains (such as wood processing) in the assessment scope (e.g. for chain-of-custody certification), no indicator set has so far been available covering environmental, social and economic aspects for the entire value chain of building with timber. However, this gap was closed through sustainability research conducted for the project "Holzwende 2020: Sustainable future markets for wood in the building sector" (Kristof and von Geibler, 2008).

The remaining article is structured as follows: first, we observe and interpret the value chain approach drawing on Gereffi (1994) and Korzeniewicz (1994) and Kaplinsky (2000) and illustrate how the value chain is coordinated and embedded in socio-ecological systems. Then we argue for a value chain wide indicator set as a crucial starting point to achieve a change in value chains towards sustainability. Hereby, the stakeholder approach provides the opportunity to systematically address life cycle effects, to consider the realities of chain actors and to provide decision support.

We present a methodological approach to develop an indicator set considering relevant stakeholders. The resulting sustainability indicator set specific for the entire value chain is presented. Next, we emphasize how the indicator set has been integrated into a decision support tool and an Internet-based learning platform. Findings from practical application of 
this tool in the building sector are highlighted, including experiences from an example of a German carpentry. Finally, conclusions are drawn on the suggested approach to improve sustainability performance of value chains.

\section{Assessing sustainability of socio-ecological systems: methods and tools from the value chain perspective}

Analysis and change of complex socio-ecological interactions are considered a major scientific challenge (see e.g. Scholz and Binder, 2004, p. 791). This challenge has to overcome both the gap between natural and social sciences as well as basic and applied research. Consequently, interdisciplinary approaches that cut across traditional disciplinary boundaries are needed, especially, if actors should accept the research results to promote a more sustainable development. Applied sustainability science moves beyond a conventional view that sees human activities as disturbances to otherwise properly functioning ecosystems, and acknowledges the need for human development at the local level and global environmental sustainability (Clark et al., 2004).

\subsection{The value chain concept}

Kaplinsky and Morris (2001) characterize the value chain as any activity necessary to get a product or service throughout different phases, from resource extraction, production and manufacturing, to consumption and finally disposal after use. Beside physical material flows, which can be assessed by material flow accounting or environmental life cycle assessments, the value chain perspective also includes other aspects such as information and monetary flows, power between actors involved as well as their position within socio-economic structures (e.g. judicial or cultural framework conditions). Figure 1 illustrates the value chain of "construction and refurbishment with wood" which can be split into six stages: resource 
extraction (forestry), wood and timber processing, construction of buildings with timber, maintenance of buildings, refurbishment of old buildings and finally recycling and disposal.

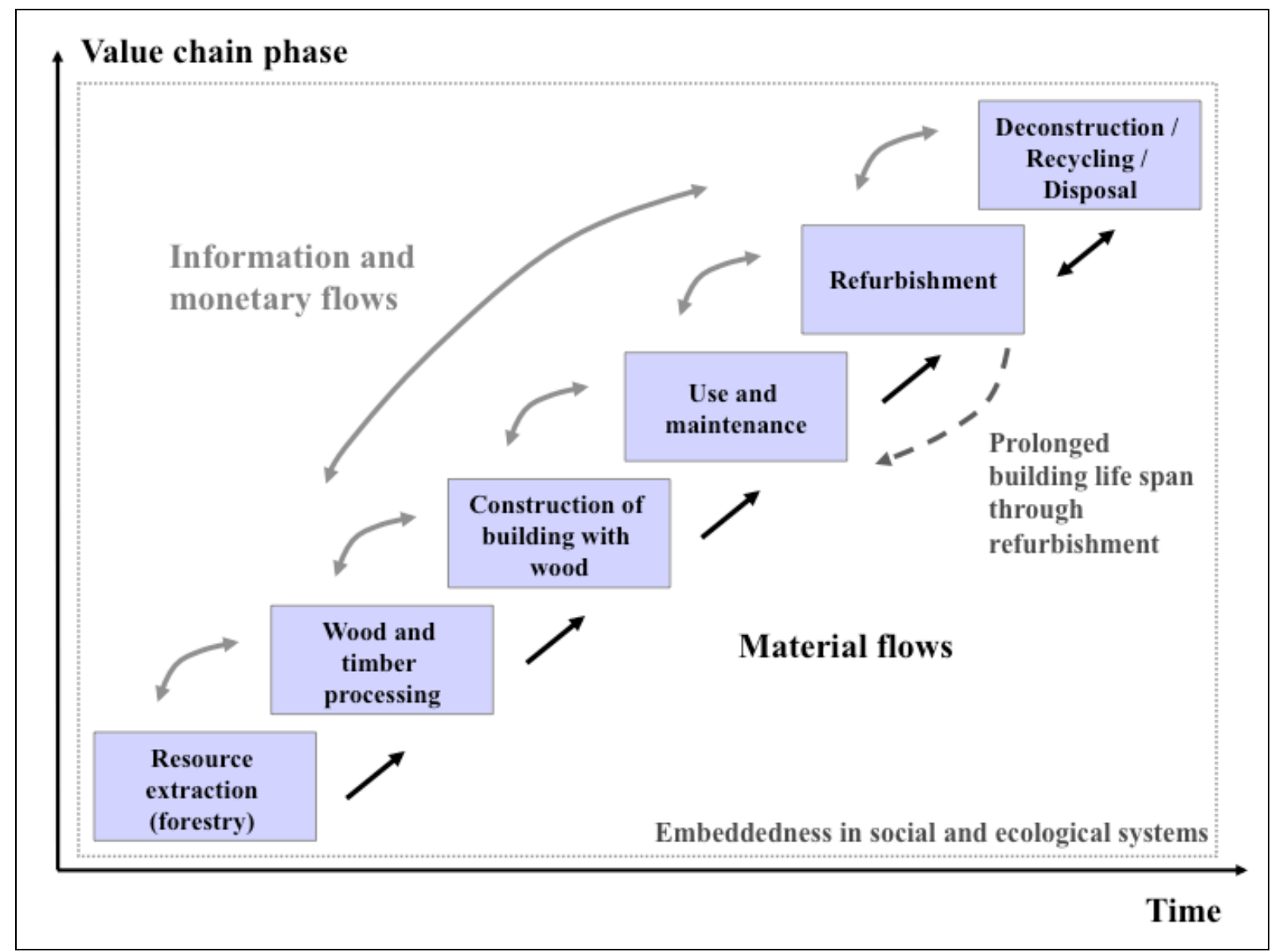

Figure 1: The value chain "construction and refurbishment with wood" (source: adopted from von Geibler, 2007)

The value chain concept broadens the primary approach of a global commodity chain developed by Gereffi and Korzeniewicz (1994) - which is the origin for the term value chain and related concepts like the French filiére-concept or management concept of supply-chains. In contrary, the value chain approach not only involves the process-interlinked material and information flows as well as their spatial distribution, but also relationships between chain actors related to control and power (Gereffi and Korzeniewicz, 1994; Altenburg, 2007). Those essentially influence the decision-making process. 
Chain actors that exert a leading and coordinating position within the chain and are able to set parameters in the entire chain are called lead agents or lead firms (Gereffi, 1999; Gereffi et al. 2001). They have the capability to control and coordinate other parts of the value chain (Humphrey und Schmitz, 2001, p. 21), which can also be shared between two or more actors. Gereffi and Korzeniewicz (1994) and Gereffi (1999) distinguish two types of lead firms, those controlling production and processing processes (producer-driven), and those controlling knowledge-intensive marketing processes (buyer-driven). Product designers are often located in product-driven lead firms. In many cases they have a substantial influence on product performance, since key decisions on the lifecycle of a product are determined in the early stages of product development. Lead agents are an important driving force of methodological developments to influence production and consumption systems as well as the ecological effects related to them. To improve product performance and to gain competitive advantages, lead actors need to gain an improved understanding of the value chain and its broader sustainability impacts.

\subsection{Sustainability of the human-environment interaction and value chains}

The fundamental definition by the Brundtland Commission characterizes sustainable development as an intergenerational concept aimed at the continued satisfaction of human needs (United Nations, 1987). In order to secure the ongoing development of social systems, the capability of ecosystems to provide services for humans is essential. Thus, sustainable development is achieved with the long-term continuity of socio-ecological interaction. Differentiating between sustainable and non-sustainable development consequently requires observing the interaction between ecosystems and social systems via indicators (Haberl et al., 2002, p. 56).

The development of indicators can be based on different framework models such as dimension-based, policy objective based, sector-based or cause-and-effect based models 
(Birkmann, 2004, p. 69). Drawing on the latter, Haberl et al. developed a process model with indicators of the socio-ecological systems (see figure 2), which focuses on the cause-andeffect chains in the interaction of societal and natural systems (Haberl et al., 2002, p. 59).

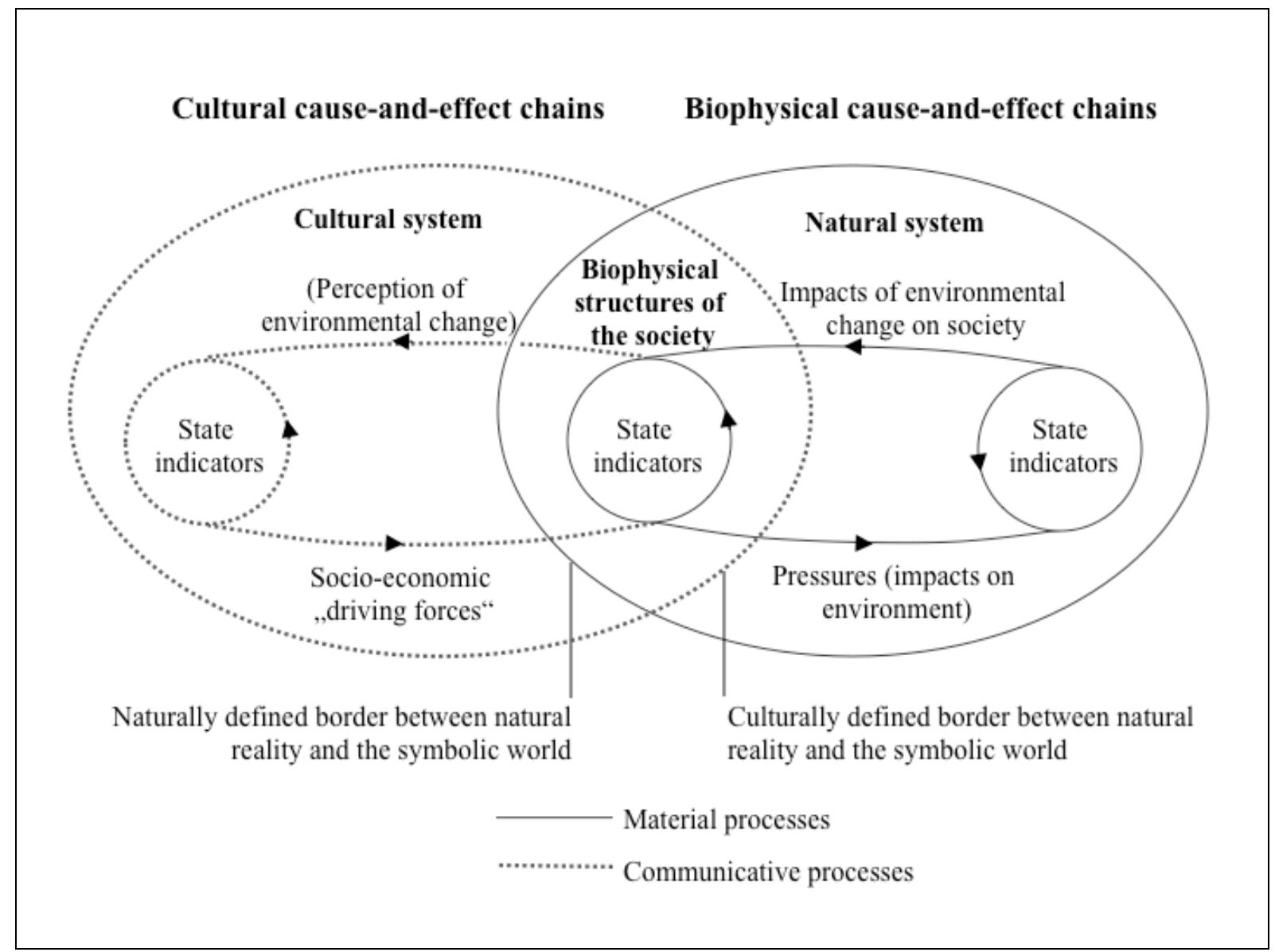

Figure 2: Process model of ecological-social interaction with reference to sustainability indicators (source: Haberl et al., 2002, p. 59)

In this model cultural and natural systems are interlinked through the biophysical structures of society. The demarcation lines are both the naturally and culturally defined borders between the natural system and the symbolic world. By distinguishing between a cultural and natural effect mechanism, this model can be used to assess indicators, which enable the observation of sustainable development. These indicators include (1) socio-economic driving forces, (2) impacts on the environment, (3) state of the environment and (4) feedback of environmental change on society. In the value chain "construction and refurbishment with wood", a specific 
biophysical structure of society, using macro-level indicators would be too broad for decisionmaking at the value chain level.

Sustainability science has accumulated considerable knowledge on models for complex socioecological interactions, as well as on tools and methods for sustainability assessments at the policy level (see e.g. de Ridder, 2005).

Also for value chains, a number of methods and tools have been developed for different scopes and levels of data gathering (site, company, supply chain, product, consumption) (e.g. Baedeker et al., 2005; Klöpffer and Renner, 2007; Schaltegger et al., 2007; Project Group on the integration of social criteria into Life Cycle Assessment, 2008). However, these often have limitations in that a number of assessment tools do not consider the entire lifecycle (Baedeker et al., 2005). In addition, indirect effects are often not considered in analyses at the value chain level due to the limited knowledge on causal links. This was shown in the biofuel debate: indirect effects gained increasing recognition, especially through the displacement of other crops by biofuels, which can result in land-use changes outside the production area (see e.g. Gallagher, et al., 2008; de Santi et al., 2008). Gallagher, et al. (2008, p. 46) e.g. concluded on indirect effects concerning greenhouse gases (GHG) that the "(q)uantification of GHG emissions from indirect land-use change requires subjective assumptions and contains considerable uncertainty". Also, the acceptance of these tools at value chain level is still limited, one reason being the partial suitability of tools as a concrete decision-making method for lead agents. A stakeholder-based approach can help to overcome these limitations.

\subsection{Stakeholder-based sustainability assessment of value chains}

Lead actors in value chains will only achieve long-term success if they significantly contribute to sustainability. The theoretical concept of sustainability has to be translated into concrete measurable results and recommendations for value chains in order to be a guiding 
principle for lead actors in the chain. Such information should enable, e.g. the product designers to integrate life-cycle sustainability aspects in product and market development. Aspects to be considered can be broad and could include for example:

- advantages and disadvantages of substitution (e.g. services instead of new products),

- fault tolerance, flexibility, reversibility of applied technology, avoidance of lock-in effects (see e.g. Weizsäcker and Weizsäcker, 1984; Simonis, 1999),

- limitation of the intensity of negative effects, avoidance of hazardous technologies (see Gleich, 1997) or

- accompanying measures to avoid psychological, technical or growth-related rebound effects (see Paech, 2005).

Indicators make the quality of decision-making in companies measurable for internal as well as external stakeholders (De Colle and Gonella, 2002). A participatory process can assist with categorizing the sustainability theory into tangible, relevant and context specific indicators (Feindt, 2002). Stakeholder consultation for the identification of appropriate indicators assists in broadening the company's assessment of current as well as future concerns (see e.g. Wilson, 1999, p. 515; Hemmati, 2002; Schaltegger and Burrit, 2005, p. 194). To prevent a biased scope of indicators, there should be a broad spectrum of stakeholders, continued reference to sustainability goals as well as an independent body conducting or monitoring the development process. Indicators should go beyond existing regulatory and economic requirements that are not negotiable such as human rights, and should consider ecological limits.

Advantages of an integrated approach to social, environmental and economic effects from corporate stakeholder engagement have been outlined in various studies (e.g. Figge et al., 2001; Hroch and Schaltegger, 2001; von Geibler et al., 2006), indicating that increasingly companies do recognize the value of detailed sustainability product performance information. 
The participation of stakeholders improves awareness of current and future (social) sustainability risks and is advantageous for decisions at the corporate level. It can support management at the operational level in order for the firm to benefit financially and to comply with existing and forthcoming regulatory guidelines. At the tactical level it improves products and services, and at the strategic level it protects a company from competitors and provides guidance on investment decisions. Thus, indicators are needed as communication tools (Schaltegger and Burritt, 2000, 2005, Kuhndt et al., 2004).

\section{Obtaining a sustainability indicator set in the case study}

Within the context of the "Holzwende 2020" project, sustainability assessments aim to direct markets within the value chains of "construction and refurbishment with wood" towards ecological, economical and social sustainability. Within the chain, a number of initiatives emerged to promote sustainable development. Criteria and standards have been set up. However, a complete analysis of the entire chain has rarely been achieved. Two far-reaching methods are the chain of custody approach for forest certification, and the natureplus label, which extends up the chain to the point of sale.

However, consumption issues or end of life aspects have not yet been integrated into value chain indicator sets (Baedeker et al., 2005). A complete value chain perspective, however, is crucial for the optimization process to prevent potential problems from shifting between different phases. 


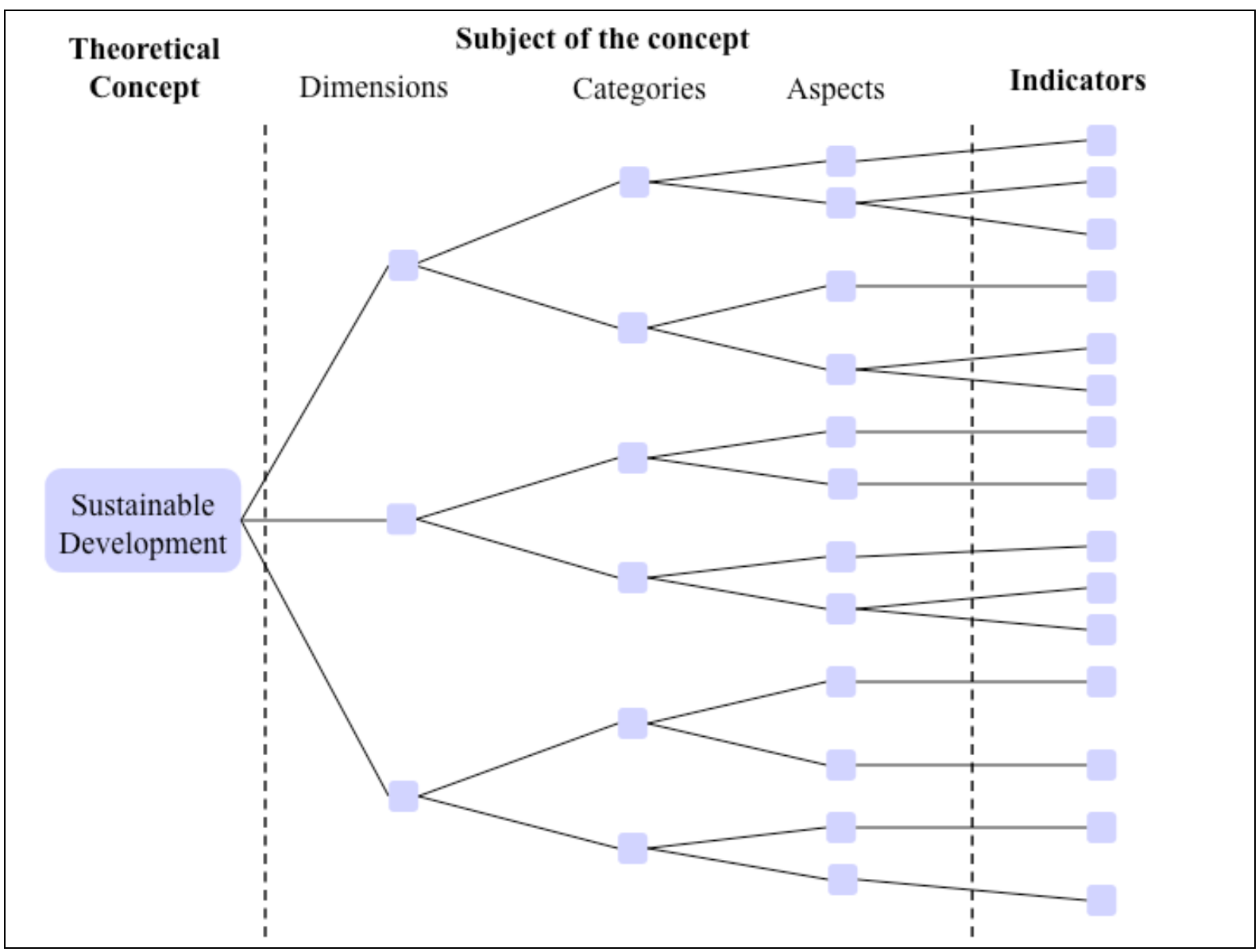

Figure 3: Concept specification for sustainable development (source: adopted from Köhler, 1987, p. 85)

The indicator set was developed on the basis of a conceptual approach, derived from the social sciences called conceptual specification or dimensional analysis (see figure 3). It can be used to break down the concept into dimensions, categories and aspects (see Kuhndt and von Geibler, 2002). This approach was applied for the development of the indicator set (see Kristof et al., 2006, for further applications see e.g. Kuhndt et al., 2004; von Geibler et al., 2006, or Global Reporting Initiative, 2006). Three methodological steps were taken to obtain the indicator set. First, based on the specification of the value chain "construction and refurbishment with wood", a literature and stakeholder analysis is conducted; based on this a preliminary indicator set is formulated. Secondly, stakeholders and specialists are consulted to provide feedback, and thirdly, the indicator set is reviewed and finalized. These steps are described in more detail below. 


\subsection{Step 1: Drafting the indicator set based on literature and stakeholder analysis}

The different value chain actors (individual companies and institutions from science, the economy, networks, etc.) are identified. The selection includes a broad range of social groups to cover the most important sustainability issues. Positions and knowledge of these actors and a wide range of initiatives are assessed regarding objectives and requirements for (parts of) the value chain. Furthermore, relevant scientific literature is reviewed (see e.g. Wallbaum, 2002). Some national and international initiatives are listed in table 1.

A review of the chain demonstrates that the entire chain is linked to significant sustainability impacts, which can be seen when taking the import of illegal timber and the building sector's resource intensiveness into consideration.

The import of tropical wood from illegal sources in Germany has been analyzed in a study by Dieter and Küpker (2006), showing that an estimated amount between 0.7 and 1.3 million $\mathrm{m}^{3}$ wood imported into Germany in 2005 originated from these sources. These figures respectively represent 34 and 65 percent of the overall German imports of tropical wood in 2005. On the global level, WWF estimates that between 20 and 40 percent of the timber is derived from illegal sources, and that the related economic loss amounts to 15 billion US dollars since wood prices are estimated to be reduced by 7 to 16 percent due to illegal logging (Hirschberger, 2008).

Table 1: Initiatives along the value chain "construction and refurbishment with wood" analyzed for indicator set development (examples) (own compilation based on Kristof et al., 2006)

\begin{tabular}{|l|l|}
\hline Value chain phase & $\begin{array}{l}\text { Sustainability initiatives (examples) } \\
\text { Ministerial Conference on the Protection of Forests in Europe (MCPFE) } \\
\text { Resource extraction } \\
\text { (forestry) }\end{array}$ \\
$\begin{array}{l}\text { addresses important issues on forests and forestry and declares recommendations for the } \\
\text { protection and sustainable management on forests in } 46 \text { European Countries and the European } \\
\text { German National Forest Program (NWP) } \\
\text { analyses environmental, social and economic benefits of forests in line with national priorities. }\end{array}$
\end{tabular}




\begin{tabular}{|c|c|}
\hline & $\begin{array}{l}\text { Strategies and measures for sustainable forest management are published } \\
\text { Forest Stewardship Council (FSC) } \\
\text { sets international standards for responsible forest management and accredits independent third } \\
\text { party organizations }\end{array}$ \\
\hline $\begin{array}{l}\text { Wood and timber } \\
\text { processing }\end{array}$ & $\begin{array}{l}\text { Chain of custody certification } \\
\text { certifies wholesalers, manufacturers, distributors, and retailers, who handle wood coming from } \\
\text { forests certified according to standards such as FSC or PEFC }\end{array}$ \\
\hline $\begin{array}{l}\text { Construction of } \\
\text { building with timber }\end{array}$ & $\begin{array}{l}\text { German Federal Ministry of Transport, Building and Urban Affairs } \\
\text { guidelines for sustainable construction to support planers with an instrument to systemically } \\
\text { implement sustainability in the construction } \\
\text { natureplus label } \\
\text { European seal of quality for building products, construction materials and home furnishings that } \\
\text { are environmentally friendly, have no negative health effects and properly perform their function }\end{array}$ \\
\hline $\begin{array}{l}\text { Use and } \\
\text { maintenance }\end{array}$ & $\begin{array}{l}\text { Holzabsatzfonds (German Timber Promotion Fund), } \\
\text { central marketing agency of the German forest and wood-based industry; promotes the use of } \\
\text { wood products to both domestic and international markets and supports research and the transfer } \\
\text { of innovation concerning wood products }\end{array}$ \\
\hline Refurbishment & $\begin{array}{l}\text { Action Program Environment and Health North Rhine Westphalia (APUG NRW) } \\
\text { addresses links between environmental and health protection; promotes to take health-related } \\
\text { aspects in refurbishments (incl. pollutant-free indoor air) into account }\end{array}$ \\
\hline $\begin{array}{l}\text { Deconstruction/recy } \\
\text { cling/disposal }\end{array}$ & $\begin{array}{l}\text { Waste Wood Ordinance (AltholzV) } \\
\text { lays down requirements for recycling, energy recovery and disposal of waste wood on the basis } \\
\text { of the Closed Substance Cycle and Waste Management Act }\end{array}$ \\
\hline $\begin{array}{l}\text { Cross-cutting } \\
\text { aspects }\end{array}$ & $\begin{array}{l}\text { Global Reporting Initiative (GRI) } \\
\text { creates guidelines provides the world's most widely used framework reporting for corporate } \\
\text { sustainability reporting } \\
\text { Integrated Product Policy (IPP) of the European Commission } \\
\text { seeks to minimize environmental impacts by looking at all phases of a products' life cycle and } \\
\text { taking action where it is most effective }\end{array}$ \\
\hline
\end{tabular}

"Construction and housing" is the field with the most significant material input in Germany, accounting for more that 15 tons of biotic and abiotic material per person annually, and thereby making up about one third of the nation's total material use (Wallbaum et al., 2005). Hence, this field is an important starting-point for a more sustainable resource use. A number of studies highlight the ecological advantages of wooden buildings (Pohlmann, 2002; German Council for Sustainable Development, 2004, Scheer et al., 2007). Consequently, wood and 
timber should play an important role in the substitution of non-renewable materials in the building sector.

\subsection{Step 2: Stakeholder interviews and expert feedback}

Through intensive discussions about balancing material, the first draft of indicator sets covering the entire chain (incl. the use and end-of-life phases) was established. However, the process of identifying key aspects and indicators is a subjective decision, with either relevant risks being left out or irrelevant issues being included (see Fürtjes, 1982, p. 38; Rennings, 1994, p. 144). Thus, the first draft of the indicator set was reviewed on the basis of a triangulation approach, i.e. the findings were verified through other experimental methods. As a result, the draft was modified based on the feedback received from interviews with a number of stakeholders. Interview partners represent different stages in the chain and different social groups. In order to cover potential effects they have also good knowledge about structures in which the value chains are embedded. Guided interviews of 45 min to 2 hours were held with 16 individuals, and transcripts were checked. The results of the interviews were analyzed both qualitatively and quantitatively to reassess and adjust the draft indicator set. In addition to the interviews, professional advice was obtained through a workshop.

Table 2: Indicator set for the value chain "construction and refurbishment with wood" for companies (source: Kristof et al., 2006, p. 19)

\begin{tabular}{|l|l|}
\hline \multicolumn{2}{|c|}{ Aspects and indicators for the distinct tiers of the value chain } \\
\hline \multirow{2}{*}{ 1. Forestry } & $\begin{array}{l}\text { Forest management according to the principles of sustainable development externally } \\
\text { certified }\end{array}$ \\
\hline Sustainable forestry & Development of synergetic effects through clustering \\
\cline { 2 - 2 } & Custom-made supply of high-quality timber products for the building sector \\
\cline { 2 - 2 } exploitation & Activities for the development of new market segments (e.g. tourism) \\
\hline \multirow{2}{*}{ 2. Industrial and handcrafted timber and wood processing } \\
\hline $\begin{array}{l}\text { Processing of regional/ } \\
\text { certified wood }\end{array}$ & Ratio of regionally produced used wood and timber \\
\cline { 2 - 2 } $\begin{array}{l}\text { Benchmarking/ } \\
\text { labelling }\end{array}$ & Ratio of certified used wood and timber \\
\hline Use cascades & Ratio of certified used wood products according to sustainability labelling guidelines \\
\hline 3. Sustainable construction and refurbishment with wood \\
\hline $\begin{array}{l}\text { Sustainability in the } \\
\text { phase of planning }\end{array}$ & Construction planning and refurbishment in order to increase wood utilization \\
& Supply of flexible design solutions/ modular systems \\
\hline
\end{tabular}




\begin{tabular}{|c|c|}
\hline & Integration of consumer, builder and contractors in the planning process \\
\hline & Integration of the use phase aspects in the evaluation of planning alternatives \\
\hline & Planning and surveying of refurbishment requirements \\
\hline \multirow{4}{*}{$\begin{array}{l}\text { Utilization of } \\
\text { sustainable wood } \\
\text { products }\end{array}$} & Ratio of regional wood-based construction material \\
\hline & Ratio of certified wood-based construction material \\
\hline & Environmental and healthy surface treatment \\
\hline & Utilization of recyclable and reusable wood construction material \\
\hline \multirow[t]{3}{*}{$\begin{array}{l}\text { Sustainability during } \\
\text { the construction phase }\end{array}$} & $\begin{array}{l}\text { Effective management of construction project and interaction between different individuals } \\
\text { involved }\end{array}$ \\
\hline & Use of broader efficiency potentials, e.g. by pre-fabricated solutions \\
\hline & Documentation of material used in construction and refurbishment \\
\hline \multicolumn{2}{|c|}{ 4. Use and maintenance of buildings } \\
\hline \multirow{2}{*}{$\begin{array}{l}\text { Improvement of living } \\
\text { quality and safety }\end{array}$} & Living quality (indoor air quality, noise reduction) \\
\hline & Safety (toxicity in case of fire, long-term stability) \\
\hline \multirow{3}{*}{$\begin{array}{l}\text { Cost efficiency in the } \\
\text { operating stage }\end{array}$} & Expenses for operation and maintenance \\
\hline & Expected life time and intervals for refurbishment \\
\hline & Opportunities for maintenance and repair incl. own contribution by inhabitant \\
\hline \multicolumn{2}{|c|}{ 5. Sustainable disposal of used building material } \\
\hline \multirow[t]{2}{*}{ Sustainable disposal } & Controlled energy use of non-recyclable wood \\
\hline & Environmentally sound disposal of wood, which cannot be reused \\
\hline \multirow{6}{*}{$\begin{array}{l}\text { Sustainable business } \\
\text { management }\end{array}$} & Value chain wide aspects and indicators \\
\hline & Sustainability business mission and monitoring of goal achievement \\
\hline & Use of environmental and/or sustainability management systems \\
\hline & Reduction of material, energy and water consumption \\
\hline & Ratio of the utilization of renewable energy and resources \\
\hline & Reduction of emission and pollution \\
\hline \multirow{5}{*}{$\begin{array}{l}\text { Sustainability } \\
\text { management in the } \\
\text { value chain (incl. } \\
\text { commerce and } \\
\text { logistics) }\end{array}$} & Sustainability requirements for suppliers \\
\hline & Reduction and optimization of transport requirements \\
\hline & Market analysis and consumer integration in sustainable product development \\
\hline & Target-group specific information on wood construction material \\
\hline & Orientation of marketing on sustainability targets \\
\hline \multirow{3}{*}{$\begin{array}{l}\text { Empowerment, } \\
\text { cooperation and } \\
\text { networking }\end{array}$} & Regular staff training on construction and refurbishment with wood \\
\hline & Cooperation through (regional) cluster management or networks \\
\hline & Cooperation with R\&D institutions (knowledge and technology transfer) \\
\hline \multirow{4}{*}{$\begin{array}{l}\text { Competitiveness and } \\
\text { innovation ability }\end{array}$} & Process and product innovations (incl. product-service system solutions) \\
\hline & Creating and securing regional employment \\
\hline & Quality assurance \\
\hline & Utilization of subsidy opportunities \\
\hline
\end{tabular}

\subsection{Step 3: Reviewing and finalizing the indicator set}

As a final step, the indicator set for the value chain "construction and refurbishment with wood" was evaluated based on stakeholder and expert feedback and finalized for application by firms and key actors in the chain. Since chain actors influence at the value chain level is limited to specific aspects, e.g. the indirect effects cannot be managed effectively at the micro level, complementary system-wide approaches were established in order to provide a sufficient knowledge base for sustainability. Thus, Kristof et al. (2006) developed a second indicator set for policy makers, which have - at least potentially - the decision-making power 
to regulate effects at the system-wide level (e.g. through integrated land use systems at national and partly international levels; see also e.g. Bringezu et al., 2007). The indicator set targeting firms is presented in table 2 (see also figure 4).

\section{$4 \quad$ Integrating the indicator set into a decision support tool}

In order to turn this indicator set into an operational tool, an Internet-based custom-made "Sustainability Check" was developed (see Kristof and Schmitt, 2007). The aim of the tool is to support a sustainability assessment of products in the value chain "construction and refurbishment with wood". The analysis of the target group indicated that most of the lead agents in the value chains of building with wood in Germany are small and medium-sized enterprises (SMEs). It became apparent that most of them could be described as novices in the field of sustainability and that they lack the resources to employ a sustainability specialist. Consequently, the "Sustainability Check" targets those entrepreneurs that are willing to evaluate the sustainability performance of either existing or future products without vast sustainability knowledge or the necessity of direct and time-consuming contact with stakeholders or consumers. In order to address specific user preferences, the "Sustainability Check" is available in both online and printed versions.

\subsection{Design of the custom-made online tool "Sustainability Check"}

Within the project, indicators from the indicator set (see table 2) were integrated into the online tool that supports the assessment of value chains in the early stages of market development, and enables a semi-qualitative self-assessment of environmental, economic and social aspects of sustainability. Considering the target group's low level of awareness and knowledge on the subject, the main objective of the "Sustainability Check" is to generate awareness about broader sustainability issues and to identify potential areas of conflict. The assessment guides the user through a custom-made, step-by-step assessment procedure. 
For the assessment procedure, multiple choice questions for each indicator set are developed.

This approach limits data input from the user and enables an evaluation within a reasonable timeframe. To further reduce the amount of information and time requirements, the user chooses one of three production-related value chain phases in which he or she is located (forestry, timber processing, building and construction). Based on this choice, a specific subset of indicators (see table 2) is generated. The subset of indicators corresponds to those indicators which the user usually has information and control over. Additionally, crossexamining questions are added to the subset, which are then grouped into categories consisting of four questions each. For example, the subset for "timber processing" includes the category "Innovation, empowerment \& networking", which covers questions regarding "Process \& product innovations", "Regular staff training", "Cluster management or networks", and "R\&D cooperations" (see figure 4). Indicating causal linkages, the questions aim to promote learning effects for the user.

Example of „timber processing“ value chain

Specific results

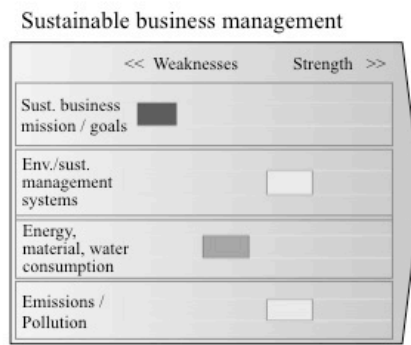

Innovation, empowerment \& networking

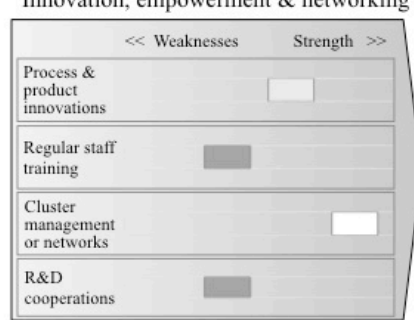

Overview

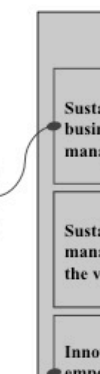

$\gamma$
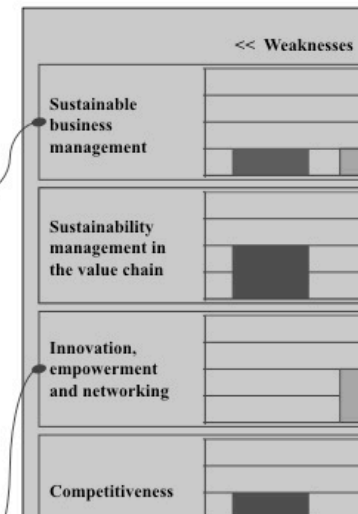

ompetitiveness
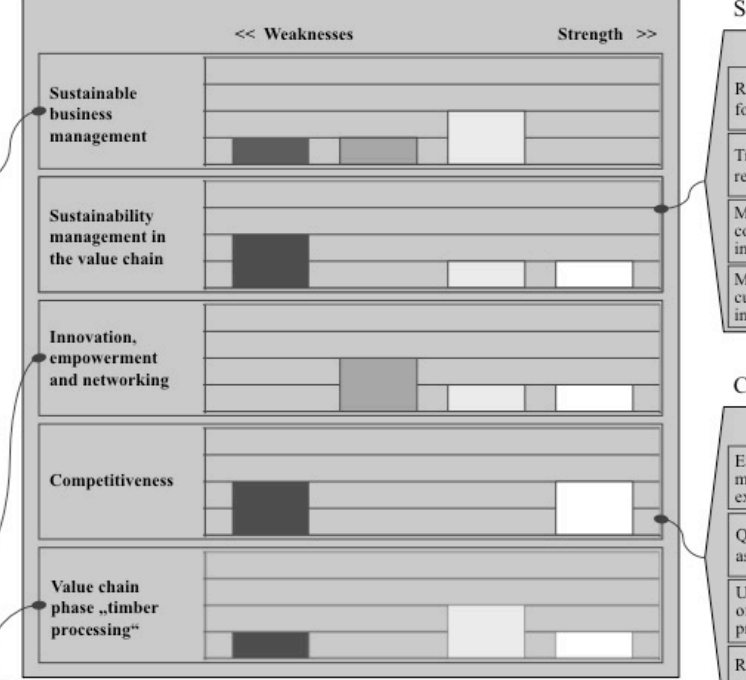
phase „timber
processing“

Specific results

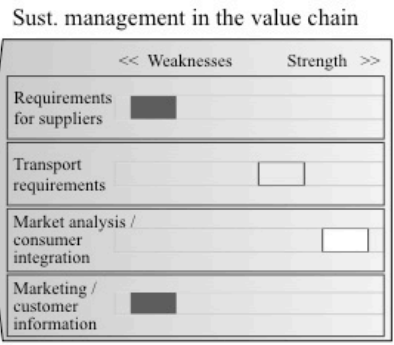

Competitiveness

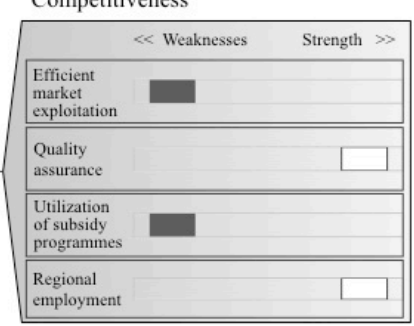

Value chain phase ,timber processing“

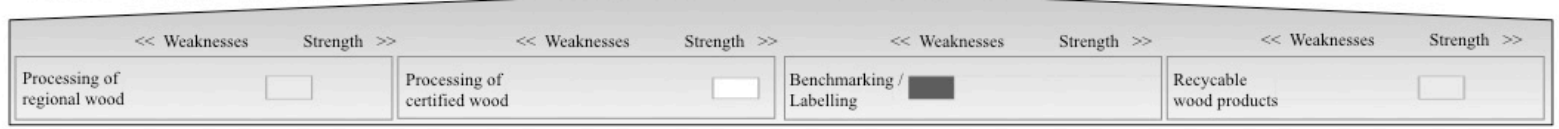


Figure 4: Results from applying the "Sustainability Check" in a carpentry (middle: overview of results for “Timber processing”, left/right/beneath: results for specific categories, source: M. Roloff based on http://holzwende2020.de/zukunftscheck)

For the assessment, the user answers the questions by marking the most appropriate of the four predefined answer options. Hereby, the first answer option to a question represents a low performance (weakness), the second equals a medium performance, the third stands for a good performance and the last option represents a very good performance (strength). By using this method, responses can be summarized for each performance group and category and presented in clearly defined diagrams using colored charts or bar graphs (see figure 4).

Linear summation of the indicator values is chosen for representing the results. For business executives the transparency and simplicity of this approach is crucial for drawing conclusions. Due to its complexity, alternate methods, such as fuzzy modelling, would not be suitable for the target group. To limit the risk of a biased interpretation of the results, the developed categories overlap as little as possible. Furthermore, results are presented in a disaggregated form.

The cumulative overview of the results should make the user more receptive to challenging areas. The sustainability category defined as critical by various relevant stakeholder groups can point to those areas that require more attention as they may include current or future risks or overlooked opportunities for innovation. Used as an inherent part of the innovation process, the online tool can raise awareness among product designers or lead actors in the chain for important perspectives beyond conventional thinking. Thus, the online tool can assist in the development of products and services, and support managerial decision-making.

The "Sustainability Check" is designed as a self-assessment tool, the user decides if the data is stored on the central server or not. The confidentiality of the data is guaranteed in order to keep entry barriers low. Explanations are given for all areas as well as for the underlying 
assessment method, to avoid misunderstandings and misleading interpretations of results. A follow-up evaluation could reveal changes that have occurred and point to either alarming or positive trends.

\subsection{Evaluation and feedback of users}

Partners of the project tested the tool in actual product developments. Five interviews were conducted to assess the users perceptions regarding the feasibility, relevance and benefits of the online tool (Schmitt and Kristof, 2007). The results show high practicability of the tool and completeness of the aspects covered in the indicator set. The tool allows a timely assessment even for product development phases with limited data availability. The interviews confirmed an increased awareness towards sustainability aspects that were previously not regarded as being part of the company's influence and responsibility. Examples of those aspects are environmental management systems, supply chain management and the integration of consumers in innovation processes. The results also indicate a benefit both to the users and to the environmental system they work in. Critical issues such as the need for links to further information were acquired and integrated in the revision of the tool.

Figure 4 illustrates the overall layout of the "Sustainability Check" by presenting the results of an application in the German carpentry "Roloff". This small carpentry with 5 employees focusses on timber processing within the value chain (see figure 4). The firm owner and master carpenter M. Roloff has used the tool for the first time and concluded that "the Sustainability Check offers a good overview of strengths and weaknesses of my company. The tool quickly points to a number of opportunities for improvement, especially in the field of marketing development”.

The "Sustainability Check" offers a starting point for sustainability management with nearly no difficulty or obstruction to the target group. The evaluation highlighted that 
complementary tools are needed: The "Sustainability Check" supports identifying conflicts between social, economic and ecological targets or between different management perspectives (e.g. maximum sustain yield vs. resilience-oriented management in forestry), but will not offer final solutions to overcome difficult trade-offs in a specific situation. Therefore, additional consultancy might be helpful. However, if an independent consultant does become necessary, the results of the assessment can support the planning process and cut related cost.

\subsection{Further tools and knowledge dissemination}

In order to complement the "Sustainability check", the "Holzwende 2020"-project team has developed, tested and evaluated a variety of other methods which can support companies and relevant organizations to promote sustainable market development in the sector building with wood. Their concrete use convinced industrial partners that the systematic use of such methods is advantageous for their businesses and leads to tangible results. It turns out that in all cases stakeholder involvement is crucial to identify key issues in the chain and facilitate the consideration of sustainability in emerging markets and the interaction between actors.

In order to communicate knowledge about the tools, various network channels were contacted. Some tools (the "Sustainability Check", the "Handwerkerprofil" and the "Resource Efficiency Calculator") were made available as web-based tools. Since potential users in the entire forest value chain need to obtain an overall knowledge about the available tools for sustainable future markets, an Internet-based learning platform (www.holzwende2020.de/lernplattform) was developed, with the German version ready for use. An English version, as well as other language editions, is still in the planning stage.

\section{Conclusion}

Since value chains are closely linked to the satisfaction of human needs and bring together different driving forces for environmental change, the optimization of value chains is an 
important approach to promote sustainable development. Hereby, covering the entire value chain is important to prevent potential problems from shifting between different value chain phases. Additionally, the optimization of a single value chain should take into account ecological limits as well as non-negotiable policy objectives such as human rights. This means that optimization might not be successful if only single life-cycle stages or only single value chains are considered. Thus, system-wide perspectives complementing the life-cycle perspective are needed in order to provide a suitable knowledge base.

The development of sustainability indicator sets for value chains and their integration into custom-made decision support tools can support development of sustainable markets. The presented methodological approach in the „Holzwende 2020”-project for the specific case study of the value chain "building and refurbishment with wood" in Germany highlighted the benefits of combining the cause-and-effect based, sector-specific and theme-oriented participatory stakeholder approaches for indicator development. Careful selection of stakeholders, consultation of experts and literature brought a diverse number of perspectives into the indicator set. In covering the entire chain, the indicator set is a novelty: other related sustainability indicator sets have only covered parts of the value chain, and the consumer and end-of-life phases, in particular, have rarely been considered. For application, the development of the decision support tool considered specific user demands of key decision makers. When not customized for a specific target group, decision support tools are likely to fail. For a widespread promotion of sustainable production and consumption patterns, the procedural approach illustrated in the case study might be transferred to sustainable market development in other sectors and other value chains and complement existing approaches to promote sustainable development. 
Sustainability goals can only be moved from the "wish level" to the "concrete implementation level" if business, politicians, society and science continue to work together to develop effective strategies. Companies are asked to adopt existing methods and tools to generate new ideas about value chain optimization. A coherent political framework (including an integrated land use system, covering food, fiber and fuel plants) should support the optimization of the value chain, which includes combinations of market-based approaches such as environmental lead technologies, product service systems as well as regulation on sustainable resource use (incl. energy). Intermediary actors of value chains (e.g. environmental NGOs, trade associations, educational institutes) should proactively engage in the promotion of sciencebased methods and tools for sustainable development. Since life-cycle assessment approaches and system-wide approaches complement each other, sustainability science will have to move beyond disciplinary boundaries to promote change towards sustainability in complex socioecological systems.

\section{Acknowledgements and additional information}

The authors gratefully acknowledge Stefan Sieber and the two anonymous reviewers for their valuable feedback. We thank Sandi Simon for editing the English text and M. Roloff for providing data from his "Sustainability Check". In addition, the authors would like to thank the German Federal Ministry for Education and Research for funding the research project "Holzwende 2020: Sustainable future markets for wood in the building sector" (grant number: 0330566 A-E). More information on the project can be found at www.holzwende2020.de.

\section{References}

Altenburg, T., 2007. Donor approaches to supporting pro-poor value chains. Report Prepared for the Donor Committee for Enterprise Development. Working Group on Linkages and Value Chains. German Development Institute, Bonn. 
Baedeker, C., Liedtke, C., Welfens, J., Busch, T., Kristof, K., Kuhndt, M., Schmitt, M., Türk, V., 2005. Analyse vorhandener Konzepte zur Messung des nachhaltigen Konsums in Deutschland einschließlich der Grundzüge eines Entwicklungskonzeptes. Analysis of Existing Concepts for Measuring Sustainable Consumption in Germany and Main Features of a Development Concept,. Wuppertal Institute, Wuppertal (in German).

Bringezu, S., Ramesohl, S., Arnold, K., Fischedick, M., Geibler, J.v., Liedtke, C., \& Schütz, H. (2007). Towards a sustainable biomass strategy: what we know and what we should know. In: A Positioning Paper of the Wuppertal Institute, Rep. No. 163. Wuppertal Institute, Wuppertal.

Birkmann, J., 2004. Monitoring und Controlling einer nachhaltigen Raumentwicklung. Monitoring and Controlling of Sustainable Spatial Development, Dortmunder Vertrieb für Bau- und Planungsliteratur, Dortmund, 372 pp. (in German).

Clark, W. C., Crutzen, P. J., Schellnhuber, H. J., 2004. Science for global sustainability. In: Schellnhuber, H. J., Crutzen, P.J., Clark, W.C., Claussen, M., Held, H. (Eds.), Earth System Analysis for Sustainability. Dahlem Workshop Report 91. MIT Press, Cambridge, Massachusetts, USA, pp. 1-28.

De Colle S., Gonella C., 2002. The social and ethical alchemy: an integrative approach to social and ethical accountability. Business Ethics: A European Review 11 (1), 86-96.

de Ridder, W. (ed.), 2005. Sustainability A-Test Inception Report: Progress to Date and Future Tasks. Netherlands Environmental Assessment Agency, A H Bilthoven, the Netherlands.

Dieter, M., Küpker, M., 2006. Die Tropenholzeinfuhr der Bundesrepublik Deutschland 1960-2005 - insgesamt und aus geschätzten illegalen Holzeinschlägen. The tropical timber import of the Federal Republic of Germany 1960-2005 - overall and from estimated illegal sources. In: Report of the Institute for Economics, 2006/1. Federal Research Centre for Forestry and Forest Products (BFH), Hamburg (in German).

de Santi, G., Edwards, R., Szekeres, S., Neuwahl, F., \& Mahieu, V. (2008). Biofuels in the European Context: Facts and Uncertainties. European Commission Joint Research Center, Institute for Environment and Sustainability Petten, the Netherlands.

Feindt, P. H., 2002. Partizipative Entwicklung von Nachhaltigkeitsindikatoren - Modell und Arbeitsprogramm. In: Wittek S., Feindt, P.H., Gessenharter, W., Hoppe, J., Seifert, E.K., Spilker, H. (Eds.), Nachhaltigkeitsindikatoren und Partizipation. Hamburg University Press, Hamburg, pp. $91-113$ (in German).

Figge, F., Hahn, T., Schaltegger, S., Wagner, M., 2001. Sustainability Balanced Scorecard. Wertorientiertes Nachhaltigkeitsmanagement mit der Balanced Scorecard. Sustainability Balanced Scorecard. Value Orientated Sustainability Management with the Balanced Scorecard. Center for Sustainability Management. University of Lüneburg, Lüneburg, 61 pp. (in German).

Fürtjes, H.-T., 1982. Das Gestaltungspotential von Instrumenten der empirischen Wirtschafts- und Sozialforschung. The Potential of Instruments used in Empirical Economic and Social Research Work. Marchal und Matzenbacher Wissenschaftsverlag, Berlin, 298 pp. (in German). 
Gallagher, E., Berry, A., Archer, G., McDougall, S., Henderson, A., Malins, C., Rose, L. 2008. The Gallagher Review of the Indirect Effects of Biofuels Production. Renewable Fuels Agency, East Sussex, 92 pp.

von Geibler, J.von, 2007. Biomassezertifizierung unter Wachstumsdruck: Wie wirksam sind Nachhaltigkeitsstandards bei steigender Nachfrage? Diskussion am Beispiel der Wertschöpfungskette Palmöl. Biomass certification under growth pressure: how effective are sustainability standards in situations of increasing demand? Discussing the case of the palm oil value chain. In: Wuppertal Paper 168, Wuppertal Institute, Wuppertal (in German with English abstract).

von Geibler, J., Liedtke, C., Wallbaum H., Schaller, S., 2006. Accounting for the social dimension of sustainability. Experiences from the biotechnology industry. In: Schaltegger, S., Burritt, R. (Guest Eds.). Special Issue on "Sustainability Accounting”. Business Strategy and the Environment 15 (5), 334-346.

Gereffi, G., 1999. International trade and industrial upgrading in the apparel commodity chain. Journal of International Economics (48), 37-70.

Gereffi, G., Korzeniewicz, M. (Eds.), 1994. Commodity Chains and Global Capitalism. Praeger, London, pp. 352.

Gereffi, G., Humphrey, J., Kaplinsky, R., Sturgeon, T.J., 2001. Introduction: globalisation, value chains and development. IDS Bulletin 32(3), 1-8.

German Council for Sustainable Development, 2004. Waldwirtschaft als Modell für nachhaltige Entwicklung. Ein neuer Schwerpunkt für die nationale Nachhaltigkeitsstrategie. Forestry as a Model for Sustainable Development. A New Focus for the National Sustainability Strategy. German Council for Sustainable Development, Berlin, pp. 24 (in German).

von Gleich, A. von, 1997. Innovationsfähigkeit und Richtungssicherheit. In: von Gleich, A. von, Leinkauf, S., Zundel, S. (Eds.), Surfen auf der Modernisierungswelle? Ziele, Blockaden und Bedingungen ökologischer Innovation. Metropolis, Marburg, pp. 15-45 (in German).

Global Reporting Initiative, 2006. Sustainability Reporting Guidelines, Version 3.0. Global Reporting Initiative, Amsterdam, the Netherlands.

Haberl, H., Fischer-Kowalski, M., Krausmann, F., Schandl, H., Weisz, H., Winiwarter, V., 2002. Theoretische Grundlagen für die gesellschaftliche Beobachtung nachhaltiger Entwicklung. Theoretical foundations of societal observation of sustainable development. Die Bodenkultur, 53, 55-63, (in German).

Hemmati, M., 2002. Multi-stakeholder Processes for Governance and Sustainability: Beyond Deadlock and Conflict. Earthscan, London, 272 pp.

Hirschberger, P., 2008. Illegaler Holzeinschlag und Deutschland: Eine Analyse der Außenhandelsdaten. 1llegal logging and Germany: Analysis of Foreign Trade Statistics, Frankfurt a. M., WWF Deutschland (in German).

Hroch, N., Schaltegger, S., 2001. Wie gut berücksichtigen Umwelterklärungen und -berichte zentrale umweltpolitische Themen?. Does Corporate Environmental Reporting Consider Topics of Current Interest 
in Environmental Politics?. Center for Sustainable Management, University of Lüneburg, Lüneburg (in German).

Humphrey, J., Schmitz, H., 2001. Governance in global value chains. IDS Bulletin 32(3), 19-29.

Kaplinsky, R., 2000. Spreading the gains from globalisation: What can be learned form value chain analysis? Journal of Development Studies 37(2), 74-115.

Kaplinsky, R., Morris M., 2001. A Handbook for Value Chain Research. International Development Research Center (IDRC), Brighton, United Kingdom.

Klöpffer, W., Renner, I., 2007. Lebenszyklusbasierte Nachhaltigkeitsbewertung von Produkten. Life-cycle Based Sustainability Assessment of Products. Technikfolgenabschätzung - Theorie und Praxis 3, 32-38 (in German).

Köhler, R., 1987. Informationen für die strategische Planung von Produktinnovationen. In: Klein-Blenkers, F. (Ed.), Distributionspolitik. Festgabe für Edmund Sundhoff zum 75. Geburtstag des Instituts für Handelsforschung. University of Cologne, Cologne, pp. 79-104.

Kristof, K., Schmitt, M., 2007. Zukunfts-Check HolzBau: Erfolgsfaktoren für Unternehmen der Wertschöpfungskette Bauen und Sanieren mit Holz. Sustainability Check Timber Construction: Success Factors for Companies of the Value Chain Construction and Refurbishment with Wood. In: Paper of the „Holzwende 2020”-Project. Wuppertal Institute, Wuppertal (in German).

Kristof, K., von Geibler, J. von (Eds.), 2008. Zukunftsmärkte für das Bauen mit Holz. DRW - Verlag Weinbrenner, Leinfelden-Echterdingen, 176 pp. (in German).

Kristof, K., Schmitt, M., Villar, A., Geibler, J. von, Lippert, F., 2006. Ziel-Indikator-System Nachhaltig Bauen und Sanieren mit Holz. Objective and indicator set for sustainable building and refurbishment with wood. In: Paper of the „Holzwende 2020”-Project. Wuppertal Institute, Wuppertal (in German).

Kuhndt, M., von Geibler, J., 2002. Developing a sectoral sustainability indicator system using the COMPASS methodology. Futura 2(2), 29-44.

Kuhndt, M., von Geibler, J., Eckermann, A., 2004. Reviewing the journey towards a sustainable aluminium industry. Stakeholder engagement and core indicators. In: Executive Project Summary for the European Aluminium Association (EAA) and the Gesamtverband der Aluminiumindustrie (GDA). Wuppertal Institute and Triple Innova, Wuppertal.

Millennium Ecosystem Assessment, 2005. Ecosystems and Human Well-being: Synthesis. Island Press, Washington, DC, 53 pp.

Paech, N., 2005. Richtungssicherheit im nachhaltigkeitsorientierten Innovationsmanagement. In: Fichter, K., Paech, N., Pfriem, R. (Eds.), Nachhaltige Zukunftsmärkte. Orientierungen für unternehmerische Innovationsprozesse im 21. Jahrhundert. Metropolis, Marburg, pp. 323-347 (in German).

Pohlmann, C., 2002. Ökologische Betrachtung für den Hausbau - Ganzheitliche Energie- und Kohlendioxidbilanzen für zwei verschiedene Holzhauskonstruktionen. Ecological reflection for building a 
house - Comprehensive energy and carbon dioxide balances for two types of wood building constructions. PhD Thesis. Universität Hamburg, Fachbereich Biologie, Hamburg, 274 pp. (in German).

Project Group on the integration of social criteria into Life Cycle Assessment, 2008. Code of Practice for a Social-economical LCA (seLCA) for Product Assessment. Unpublished third draft. UNEP/SETAC Life Cycle Initiative.

Rennings, K., 1994. Indikatoren für eine dauerhaft-umweltgerechte Entwicklung. Indicators for a long-term environmentally sound development. In: Issue 24 of "Materialien zur Umweltforschung" of the Advisory Council on the Environment (SRU). Metzler-Poeschel, Stuttgart, 226 pp. (in German).

Schaltegger, S., Burritt, B., 2000. Contemporary Environmental Accounting. Greenleaf, Sheffield, 462 pp.

Schaltegger, S., Burritt, B., 2005. Corporate sustainability. In: Folmer, H., Tietenberg, T. (Eds.), The International Yearbook of Environmental and Resource Economics 2005/2006. A Survey of Current Issues. Edward Elgar, Cheltenham, pp. 185-222.

Schaltegger, S., Herzig, C., Kleiber, O., Klinke, T., Müller, J., 2007. Nachhaltigkeitsmanagement in Unternehmen: Von der Idee zur Praxis. Sustainability management in enterprises: from idea to practice. BMU/Econsense/CSM, Berlin/Lüneburg, 194 pp. (in German).

Scheer, D., Feil, A., Zerwer, C., 2007. Nachhaltigkeit im Bereich Bauen und Wohnen. Ökologische Bewertung der Bauholz-Kette. Sustainability of Construction and Living. Ecological Assessment of Construction Wood Chain. Institut für ökologische Wirtschaftsforschung, Heidelberg (in German).

Schmitt, M., Kristof, K., 2007. Evaluation der Methodennutzung in den Praxisprojekten. Evaluation of methods applied in the implementation projects. In: Paper of the „Holzwende 2020”-Project, Wuppertal Institute, Wuppertal (in German).

Scholz, R.W., Binder, C.B. 2004. Principles of Human-Environment Systems (HES) Research. In: Pahl, C., Schmidt, S., Rizzoli, A. E., Jakeman, T. (Eds.), Complexity and Integrated Resources Management Transactions of the 2nd Biennial Meeting of the International Environmental Modelling and Software Society. Zentrum für Umweltkommunikation, Osnabrück, Germany, pp. 791-796.

Simonis, G., 1999. Die Zukunftsfähigkeit von Innovationen: das Z-Paradox. In: Sauer, D., Lang, C. (eds.), Paradoxien der Innovation. Campus, Frankfurt, New York, pp. 149-173 (in German).

United Nations, 1987. Report of the World Commission on Environment and Development. General Assembly Resolution 42/187, United Nations.

Wallbaum, H., 2002. Denk- und Kommunikationsansätze zur Bewertung des nachhaltigen Bauens und Wohnens. Approaches of thinking and communicating towards a sustainable construction and habitation. PhD Thesis. University of Hannover, Germany, 264 pp. (in German).

Wallbaum, H., Müller, M., Kaiser, C., 2005. Ressourceneffizienz am Bau ist planbar. Resource Efficiency in Construction can be Planned. FactorY 03/2005, p. 16 (in German). 
von Weizsäcker, C. von Weizsäcker, E.U., 1984. Fehlerfreundlichkeit. In: Kornwachs, K. (Ed.), Offenheit, Zeitlichkeit, Komplexität. Campus, Frankfurt, New York, pp. 167-201 (in German).

Wilson, A., 1999. Social reporting: developing theory and current practice. In: Bennett, M., James, P. (Eds.), Sustainable Measures: Evaluation and Reporting of Environmental and Social Performance. Greenleaf, Sheffield, pp. 509-528. 